Tomasz R. SZYMCZYŃSKI

Uniwersytet im. Adama Mickiewicza, Poznań

\title{
Droga Austrii do czlonkostwa w Unii Europejskiej
}

\author{
„Jesteśmy Europą” \\ motto przedreferendalnej kampanii informacyjnej w Austrii ${ }^{1}$
}

\section{Wprowadzenie}

Przełom lat osiemdziesiątych i dziewięćdziesiątych XX wieku przynosi daleko idące zmiany na płaszczyźnie międzynarodowej. Wraz z upadkiem Związku Radzieckiego konflikt na linii Wschód-Zachód, który kształtował podstawowe kwestie na politycznej arenie świata przez cztery dekady przestał istnieć. Pośród wielu istotnych konsekwencji tej sytuacji, powyższe wydarzenie otworzyło także nowe możliwości dla państw, które w okresie bipolarnego porządku na świecie prezentowały postawę neutralną. Jako pierwsza z projektem wejścia do Wspólnot Europejskich wystapiła Austria, której - co warte podkreślenia - regulacje dotyczące kwestii neutralnego statusu miały znacznie bardziej restrykcyjny charakter, niż w pozostałych europejskich państwach neutralnych. Powyższa postawa Wiednia przyczyniła się do zmiany tradycyjnej postawy Szwecji względem Wspólnot, co z kolei w znaczący sposób zwiększyło zainteresowanie akcesją trzeciego państwa, który w trakcie Zimnej Wojny również prezentował postawę neutralną - Finlandii. Do grona powyższych państw dołączyła również Norwegia, jedyny z powyższych państw członek NATO. Ostatecznie jednak Norwegia uzyskała członkostwo jedynie w Europejskim Obszarze Gospodarczym, który można określić jako istotny pierwszy krok w stosunku do wejścia do UE, ponieważ w 1994 roku w referendum ogólnonarodowym społeczeństwo norweskie powtórzyło swoją negatywną opinię na temat akcesji, którą po raz pierwszy wyraziło

1 „Wir sind Europa” było głównym hasłem informacyjnej kampanii przedreferendalnej w Austrii. Por. M. Leska, A. Ostrowska, Drogi do Unii Europejskiej. Narodowe strategie informacyjne, Warszawa 1998. 
po wynegocjowaniu akcesji do struktur wspólnotowych w 1972 roku. Wydaje się, że w powyższym kontekście przypadek austriacki zasługuje na szczególną uwagę. Wynika to z faktu bardzo skomplikowanej historii austriackiego państwa ${ }^{2}$, dylematów związanych z interpretacją statusu neutralności, jak też specyfiki formy kampanii informacyjnej, jaka miała w Austrii miejsce w okresie poprzedzającym referendum akcesyjne w 1994 roku.

W artykule 1 uchwalonego w 1955 roku Austriackiego Traktatu Państwowego zawarty został zapis o permanentnej neutralności środkowoeuropejskiego państwa. Powyższe rozwiązanie pozwalało uzyskać austriackiemu państwu status suwerenności. Jednocześnie neutralność oznaczała pozostawanie Wiednia poza głównym nurtem procesu integracji europejskiej, który wówczas zaczynał przybierać realne kształty. Nowe możliwości na powyższej płaszczyźnie pojawiły się wraz ze zmianami zachodzącymi u schyłku lat osiemdziesiątych na świecie. Republika Austrii, która niemal w całym okresie powojennym wykazywała daleko idące zainteresowanie kwestiami procesu zjednoczeniowego na starym kontynencie, jako pierwsza z grona państw neutralnych, 17 lipca 1989 roku, złożyła oficjalny wniosek o członkostwo we Wspólnotach Europejskich.

Należy jednocześnie podkreślić, iż w zasadzie od chwili sformalizowania statusu neutralności, Wiedeń interpretował powyższe rozwiązanie jako „neutralność aktywną”, co w praktyce oznaczało aktywność zarówno na płaszczyźnie polityki międzynarodowej, jak również partycypację w szeregu organizacji międzynarodowych, w czym uwidaczniają się w znacznym stopniu różnice $\mathrm{w}$ stosunku do neutralnej Szwajcarii ${ }^{3}$.

\section{Polityczna pozycja Austrii przed wejściem do Unii Europejskiej}

27 kwietnia 1945 roku został utworzony pierwszy - prowizoryczny rząd II Republiki, którego kanclerzem został Karol Renner. W jego skład

2 Por. B. Koszel, Austria w procesie integracji Polski z Unia Europejska, „Opinie", MSZ, Warszawa 2003. s. 3 i n.

Członkostwo w ONZ, organizacji o charakterze uniwersalnym spowodowało przy tym znacznie mniej kontrowersji niż uzyskanie miejsca w Radzie Europy przez Austrię, która to organizacja w praktyce przeznaczona była w okresie zimnej wojny wyłącznie dla krajów Europy Zachodniej. Szerzej patrz: P. Luif, Österreich, w: Europa-Handbuch, Hrsg. W. Weidenfeld, Bonn 1999, s. 183 i n. 
weszło po dziewięciu przedstawicieli SPÖ oraz ÖVP, jak też siedmiu reprezentantów Komunistycznej Partii Austrii. Po uznaniu powyższego organu przez władze radzieckie dopiero zmiany w jego składzie spowodowały zgodę na jego istnienie ze strony pozostałych państw okupujących. 25 listopada 1945 roku odbyły się wybory do Rady Narodowej i sejmów krajowych, w których ÖVP uzyskała 85 mandatów, SPÖ 76 miejsc, a komuniści tylko 4 mandaty, co zostało przez austriackie społeczeństwo odebrane jako duża niespodzianka. W ramach porozumienia koalicyjnego pomiędzy ÖVP oraz SPÖ został utworzony rząd, którego kanclerzem został, reprezentujący ludowców, Leopold Figl. Natomiast Prezydentem państwa po jednomyślnym głosowaniu w Zgromadzeniu Związkowym wybrany został Karol Renner ${ }^{4}$.

Powyższe wydarzenia nie oznaczały niepodległości Austrii. Władzę sprawowała w dalszym ciagu Rada Sojusznicza, w której skład wchodziły cztery państwa alianckie: Stany Zjednoczone, Związek Radziecki, Wielka Brytania oraz Francja. W konsekwencji głównym celem austriackiego rządu było doprowadzenie do odzyskania przez Republikę Austrii pełnej niepodległości. Negocjacje w tej sprawie ciagnęły się przez wiele lat i dopiero śmierć Józefa Stalina w 1953 roku i odwilż we wzajemnych relacjach pomiędzy Waszyngtonem i Moskwą, która następnie nastąpiła, pozwoliły na postęp w powyższej kwestii. Austriacki Traktat Państwowy który został podpisany 15 maja 1955 roku - przyznawał Austrii suwerenność, czego bezpośrednim praktycznym przejawem było wycofanie się wojsk sojuszniczych z okupowanego wcześniej terytorium ${ }^{5}$. Paul Luif podkreśla przy tym wagę samej nazwy traktatu - ,państwowy”, a nie „,pokojowy", co wynika z faktu, iż po wkroczeniu nazistowskich Niemiec na teren Austrii w 1938, kraj ten nie stanowił samodzielnej jednostki decyzyjnej w okresie wojny ${ }^{6}$. W powyższym kontekście na uwagę zasługuje także fakt, iż zapis w art. 1 ustawy dotyczącej statusu wieczystej neutralności Austrii, którą austriacki parlament uchwalił 26 października 1955 roku, podkreśla, iż kraj ten na tego rodzaju rozwiązanie zdecydował się z własnej woli ${ }^{7}$.

${ }^{4}$ H. Wereszycki, Historia Austrii, Wrocław-Warszawa-Kraków-Gdańsk-Lódź 1986, s. 304-305.

${ }^{5}$ V. M. Reyes, Reguły gry czyli o negocjacjach akcesyjnych i łqczeniu się Europy, Warszawa 2000, s. 147.

${ }^{6}$ P. Luif, Österreich ..., s. 194.

7 Österreichisches Bundesgesetzblatt Nr 211/1955, art. 1, ust. 1. 
Jeszcze w latach czterdziestych XX wieku Wiedeń stanął przed poważnym dylematem, który spowodowany był czytelnym konfliktem pomiędzy poszczególnymi celami strategicznymi austriackiego rządu. Na płaszczyźnie gospodarczej pragnienie partycypacji w Planie Marshalla nie budziło wątpliwości, natomiast z politycznego punktu widzenia mogło doprowadzić do pogorszenia relacji z ZSRR, co z kolei przekładało się na znacznie mniej optymistyczne perspektywy co do uzyskania pełnej niepodległoś$\mathrm{ci}^{8}$. Należy zatem zgodzić się z opinią, iż uczestnictwo Austrii przy powstaniu OEEC, pośród siedemnastu państw założycielskich w żadnym razie nie wolno uznać za sprawę oczywistą ${ }^{9}$.

Choć ograniczenia suwerenności Austrii nie przeszkodziły jej w uczestnictwie w realizacji Planu Marshalla od 1947 roku, dopiero uregulowanie kwestii statutowych państwa oznaczało podwyższenie aktywności Wiednia na arenie międzynarodowej. 15 grudnia 1955 roku Austria stała się członkiem ONZ, a po wzięciu udziału w zakończonych fiaskiem tzw. negocjacjach Moudlinga $^{10}$, Austria stała się członkiem-założycielem Europejskiego Stowarzyszenia Wolnego Handlu - EFTA, które szczególnie w swej wstępnej fazie w dużej mierze skonstruowane było jako alternatywa $\mathrm{w}$ stosunku do EWG ${ }^{11}$. Tego rodzaju rozumienie relacji pomiędzy EWG i EFTA odmieniło się diametralnie, po tym, gdy Wielka Brytania - inicjator i państwo przewodzące Europejskiemu Stowarzyszeniu Wolnego Handlu - zgłosiła swoje zainteresowanie pełnym uczestnictwem $\mathrm{w}$ procesie integracji w ramach trzech Wspólnot Europejskich ${ }^{12}$. W ra-

8 G. Falkner, The Europeanisation of Austria: Misfit, Adaptation and Controversies, „European Integration online Papers - EIoP”, Vol. 5, No. 13, December 2001, s. 1.

9 F. Urlesberger, Die Marginalisierung Österreichs im europaeischen Integrationsgeschehen nach Aufloesung der OEEC/OECD, w: Österreichs Integration in Europa 1948-1989, Wien 1990, s. 20.

10 Negocjacjami Moudlinga (ang.: Moudling Talks) nazywane są zainicjowane przez Brytyjczyków rozmowy, których przedmiotem był projekt utworzenia na bazie organizacji sześciu państw założycielskich EWWiS oraz EWG nowej organizacji, która objęłaby wszystkie państwa OEEC.

11 D. Phinnemore, Austria, Transit and the Environment, w: The 1995 Enlargement of the European Union, ed. J. Redmond, Aldershot 1997, s. 65.

$12 \mathrm{Na}$ temat skomplikowanych relacji pomiędzy Wspólnotami Europejskimi i Zjednoczonym Królestwem patrz szerzej: T. R. Szymczyński, Od planu Schumana do weta de Gaulle'a. Wielka Brytania poza procesem integracji europejskiej 1950-1963, „Przegląd Politologiczny” 2003, nr 1, s. 7-22; T. R. Szymczyński, Droga Wielkiej Brytanii do członkostwa we Wspólnotach Europejskich - 1964-1975, „Przegląd Politologiczny” 2003, nr 4, s. 27-40, T. R. Szymczyński, Kontrowersje wokót po- 
mach końcowej fazy dochodzenia Zjednoczonego Królestwa do pełnego członkostwa we WE, w 1972 roku osiagnięto także porozumienie o utworzeniu strefy wolnego handlu pomiędzy EWG i EFTA, co zinterpretować należy jako kolejny krok przybliżający neutralną Austrię do integracyjnych struktur wspólnotowych ${ }^{13}$.

Należy również wspomnieć, iż po odzyskaniu pełnej suwerenności przez Austrię w zasadzie jedynym istotnym problemem na płaszczyźnie stosunków międzynarodowych pozostawała dla Wiednia nieuregulowana kwestia południowego Tyrolu, obszaru znajdującego się na granicy włosko-austriackiej, który na podstawie traktatu pokojowego z Saint-Germain z 1919 roku został w całości włączony do Włoch. Na tej podstawie pomiędzy Rzymem i Wiedniem rozwinął się konflikt, który rozwiązany został dopiero pod koniec lat sześćdziesiątych XX wieku, a który w połowie lat sześćdziesiątych miał także przyczynić się do odsunięcia Austrii od struktur wspólnotowych ${ }^{14}$.

\section{Ekonomiczna pozycja Austrii przed wejściem do Unii Europejskiej}

Ryzykowna decyzja władz austriackich na przełomie czerwca i lipca 1947 roku, by - w przeciwieństwie do państw bloku wschodniego - wziąć udział w programie pomocy określanej jako Plan Marshalla już wówczas wyznaczyła zachodni kierunek aktywności gospodarczej Austrii ${ }^{15}$. W zasadzie od początku starała się ona o jak najbliższe relacje gospodarcze z państwami zachodniej Europy, choć pełne uczestnictwo w tworzących się wówczas Wspólnotach Europejskich nie wchodziło w grę ze względu na status suwerenności. Powyższą sytuację należy określić jako wysoce

stawy Wielkiej Brytanii względem procesu zjednoczeniowego w Europie Zachodniej po II wojnie światowej, w: Dylematy integracji europejskiej. Europa Środkowo-Wschodnia u progu rozszerzenia Unii Europejskiej, red. R. Kmieciak, T. Wallas, UAM, Poznań 2004, s. 91-104.

13 G. Eisl, Austria's Experiences before and after its Entry to the European Union, w: The Experiences of the 1995 Enlargement. Sweden, Finland and Austria in the European Union, eds. J. Jańczak, T. R. Szymczyński, Logos; „Thematicon”, Bd 9, Berlin 2003, s. 41-49.

14 Na temat konfliktu wokół południowego Tyrolu szerzej patrz: H. Wereszycki, Historia ..., s. 308-309.

15 P. Luif, Österreich ..., s. 184. 
niekorzystną z perspektywy gospodarczej, ponieważ pozostawanie poza EWG utrudniało tradycyjne oraz niejako naturalne z perspektywy bliskości geograficznej kontakty handlowe z dwoma dużymi państwami założycielskimi WE - Niemcami Zachodnimi oraz Włochami.

Tabela 1

Struktura handlu zagranicznego Austrii w wybranych latach 1970-1990 (\%)

\begin{tabular}{||l|r|r|r|r|r|r||}
\hline \multirow{2}{*}{} & $\mathbf{1 9 7 0}$ & $\mathbf{1 9 8 0}$ & $\mathbf{1 9 9 0}$ & $\mathbf{1 9 7 0}$ & $\mathbf{1 9 8 0}$ & $\mathbf{1 9 9 0}$ \\
\cline { 2 - 7 } & \multicolumn{3}{|c|}{ EKSPORT } & \multicolumn{3}{c||}{ IMPORT } \\
\hline WE & 39,4 & 55,2 & 64,5 & 56,0 & 62,4 & 68,3 \\
\hline EFTA & 25,3 & 12,4 & 10,1 & 19,1 & 7,9 & 7,1 \\
\hline Europa Wsch.** & 12,9 & 12,1 & 8,5 & 9,3 & 9,7 & 6,0 \\
\hline OPEC & b.d.* & 5,6 & 2,7 & b.d.* & 7,1 & 2,1 \\
\hline RFN & 23,4 & 30,8 & 36,7 & 41,2 & 40,8 & 43,7 \\
\hline Szwajcaria & 10,4 & 7,5 & 6,9 & 7,4 & 5,0 & 4,3 \\
\hline Włochy & 9,7 & 11,0 & 9,8 & 6,8 & 2,7 & 2,6 \\
\hline W. Brytania & 6,1 & 3,7 & 3,9 & 6,5 & 9,1 & 9,1 \\
\hline USA & 4,1 & 2,2 & 3,2 & 3,5 & 3,9 & 4,2 \\
\hline Holandia & 2,9 & 2,6 & 2,9 & 3,4 & 3,4 & 3,6 \\
\hline ZSRR & 2,9 & 2,7 & 2,2 & 2,9 & 2,7 & 2,8 \\
\hline Francja & 2,2 & 3,5 & 4,8 & 2,2 & 4,2 & 1,8 \\
\hline Japonia & 0,5 & 0,8 & 1,6 & 1,0 & 2,4 & 4,5 \\
\hline
\end{tabular}

* - b.d.- brak danych.

** - bez ZSRR.

Źródło: Österreichisches Statistisches Zentralamt, Statistisches Handbuch für die Republik Österreich, 1972, Wien 1972, s. 196-197; Österreichisches Statistisches Zentralamt, Statistisches Handbuch für die Republik Österreich, 1982, Wien 1982, s. 369; Österreichisches Statistisches Zentralamt, Statistisches Handbuch für die Republik Österreich, 1991, Wien 1991, s. 310.

Fritz Breuss ${ }^{16}$ podkreśla niewykorzystane szanse rozwoju gospodarczego w Europie Zachodniej ze względu na dwutorowość procesu integracyjnego, w którym po jednej stronie znalazły się państwa członkowskie Europejskiej Wspólnoty Gospodarczej, a po drugiej kraje należące do Europejskiego Stowarzyszenia Wolnego Handlu. Nie można się nie zgodzić, iż z perspektywy stricte gospodarczej powyższa teza posiada swoje

16 F. Breuss, Austria's Approach towards the European Union, IEF Working Paper $\mathrm{Nr}$ 18, April 1996. 
uzasadnienie $^{17}$. Niezależnie od kontrowersji powyższego twierdzenia, z pewnością protekcjonistyczny charakter obu ugrupowań potwierdzają dane statystyczne. W roku 1960, a zatem w momencie ukonstytuowania EFTA, 50,3\% całkowitego eksportu Austrii trafiało na rynek „Szóstki”, by w roku 1972 powyższa wielkość wynosiła już tylko 38,7\%, przy czym w 1960 roku udział Austrii we wspólnotowym rynku wynosił 1,8\%, natomiast po dwunastu latach pozostawania poza EWG zmniejszył się on do 1,2\%. Dla odmiany trafiająca na rynki państw EFTA część austriackiego eksportu wynosiła w roku 1960 13,2\%, by w 1972 roku powiększyć się do $29 \%{ }^{18}$.

Tabela 2

Sektorowy podzial PKB w wybranych latach 1970-1990 (\%)

\begin{tabular}{||l|r|r|r|r||}
\hline \multicolumn{1}{|c|}{ Sektor } & $\mathbf{1 9 6 0}$ & $\mathbf{1 9 7 0}$ & $\mathbf{1 9 8 0}$ & $\mathbf{1 9 9 0}$ \\
\hline Rolnictwo i sektor leśny & 11,1 & 6,9 & 4,4 & 3,1 \\
\hline Sektor wytwórczy i wydobywczy & 36,6 & 34,4 & 28,3 & 26,6 \\
\hline Sektor energetyczny i wodny & 2,8 & 2,8 & 3,1 & 2,5 \\
\hline Budownictwo & 7,6 & 8,2 & 8,2 & 7,0 \\
\hline Handel i turystyka & 15,5 & 18,1 & 16,8 & 16,4 \\
\hline Transport i komunikacja & 6,0 & 5,9 & 5,8 & 6,2 \\
\hline Administracja posiadłości & 6,2 & 8,4 & 12,0 & 16,7 \\
\hline Inne usługi & 2,9 & 3,0 & 3,2 & 4,0 \\
\hline Inne & 10,9 & 11,9 & 13,7 & 13,8 \\
\hline Opłaty importowe & 2,7 & 3,5 & 0,6 & 0,7 \\
\hline VAT & b.d.* & b.d.* & 8,5 & 8,8 \\
\hline Razem** & 100,0 & 100,0 & 100,0 & 100,0 \\
\hline
\end{tabular}

* - b.d. - brak danych.

** - ze względu na przybliżone dane suma poszczególnych wskaźników nie musi równać się 100\%. Źródlo: Österreichisches Statistisches Zentralamt, Statistisches Handbuch für die Republik Österreich, 1991, Vienna 1991, s. 210.

Niezależnie od powyższych niedogodności Austria nadzwyczaj dobrze zniosła negatywne konsekwencje pierwszego kryzysu naftowego z 1973 roku. Wynikało to w dużej mierze ze specyfiki jej gospodarki, któ-

17 Breuss w swojej tezie nie bierze przykładowo pod uwagę różnic co do celów integracyjnego procesu pomiędzy państwami, jak też innych czynników, które odgrywały w omawianej sytuacji ważną rolę, a wśród których wystarczy wymienić odmienną strukturę podziału władzy w ramach organizacji w zależności od tego które z krajów się w niej znajdują, różny poziom komplementarności założonych celów strategicznych poszczególnych krajów i to zarówno na płaszczyźnie politycznej, jak też ekonomicznej, etc.

18 F. Breuss, Austria's ..., s. 2-3. 
ra w znacznym stopniu oparta była na sektorze publicznym. Już w lipcu 1946 roku koalicyjny rząd ludowców i socjalistów wprowadził ustawę o upaństwowieniu dużych banków oraz kluczowych przemysłów ${ }^{19}$. W rezultacie państwo miało duży wpływ na obszar gospodarki, a polityka którą kolejne rządy wyznawały zyskała nazwę ,,austriackiego keynesizmu". Zakładająca priorytetowe traktowanie kwestii pełnego zatrudnienia powyższa polityka liczyła się z możliwością zwiększenia zadłużenia państwa w okresie kryzysu w celu utrzymania dotychczasowego poziomu miejsc pracy $^{20}$.

Interesująco prezentuje się ewolucja udziału poszczególnych sektorów w tworzeniu PKB Austrii (tab. 2) wraz ze zmieniającą się strukturą zatrudnienia (tab. 3) z perspektywy wpływu powyższych zjawisk na wewnętrzną scenę polityczną. Zmniejszająca się liczba pracowników zatrudnionych w sektorze rolnym przekładała się na malejące szanse tradycyjnie związanej ze wsią Partii Ludowej - ÖVP, przy czym powyższą zależność zilustrować można, porównując wyniki kolejnych wyborów powszechnych w Austrii (tab. 4).

Tabela 3

Udzial sily roboczej w poszczególnych sektorach, 1970-1990 (\%)

\begin{tabular}{||l|r|r|r||}
\hline \multicolumn{1}{|c|}{ Sektor } & $\mathbf{1 9 7 0}$ & $\mathbf{1 9 8 0}$ & $\mathbf{1 9 9 0}$ \\
\hline Rolnictwo i sektor leśny & 18,8 & 10,5 & 7,9 \\
\hline Sektor wydobywczy & 1,0 & 0,6 & 0,4 \\
\hline Sektor wytwórczy & 30,0 & 29,5 & 27,0 \\
\hline Sektor elektryczny, gazowniczy i wodny & 1,1 & 1,3 & 1,2 \\
\hline Budownictwo & 8,2 & 8,8 & 8,4 \\
\hline Handel hurtowy, detaliczny, restauracje, hotele & 14,2 & 17,1 & 18,6 \\
\hline Transport, magazynowanie, handel & 6,3 & 6,3 & 6,4 \\
\hline Finanse, ubezpieczenia, doradztwo biznesowe & 3,4 & 5,0 & 6,5 \\
\hline Doradztwo personalne, społeczne & 16,5 & 20,8 & 23,7 \\
\hline Aktywność nie zdefiniowana & 0,3 & 0,1 & - \\
\hline Razem* & 100,0 & 100,0 & 100,0 \\
\hline \hline
\end{tabular}

* - ze względu na zaokrąglenia suma poszczególnych wskaźników nie musi równać się 100\%.

Źródło: Österreichisches Statistisches Zentralamt, Statistisches Handbuch für die Republik Österreich, 1991, Vienna 1991, s. 108; Organisation for Economic Co-operation and Development, OECD Economic Surveys, 1991-1992: Austria, Paris 1992, s. 160-161.

19 H. Wereszycki, Historia ..., s. 306.

20 V. Lauber, Wirtschafts- und Finanzpolitik, w: Handbuch des politischen Systems Österreichs, Wien 1997, s. 551. 
Podsumowując skrótowe zestawienie specyficznych atrybutów gospodarki Austrii, nie wolno również nie wspomnieć, iż współpraca pomiędzy dwiema najsilniejszymi partiami, której efektem było stworzenie austriackiej wersji państwa dobrobytu w latach pięćdziesiątych XX wieku zostało dodatkowo poparte pojawieniem się tzw. partnerstwa społecznego (niem.: die Sozialpartnerschaft), przy czym właściwie układająca się współpraca pomiędzy pracodawcami i pracownikami przy udziale rządu dawała solidny grunt dla powstania w Austrii systemu korporacyjnego na płaszczyźnie w zasadzie całego społeczeństwa ${ }^{21}$.

\section{Proces dochodzenia Austrii do członkostwa w Unii Europejskiej}

Proces dochodzenia Austrii można podzielić na trzy zasadnicze etapy. Pierwszy obejmuje okres, pomiędzy zakończeniem drugiej wojny światowej a podpisaniem przez Austrię oraz pozostałe państwa EFTA umowy o wolnym handlu z krajami EWG w 1972 roku $^{22}$. Powyższe wydarzenie rozpoczyna jednocześnie drugi etap, który trwał do zakończenia zimnej wojny. Choć określenie dokładnej daty początku etapu trzeciego może przysporzyć pewne komplikacje, należy przyjąć, iż rozpoczął się on u schyłku lat osiemdziesiątych XX wieku, kiedy to elity decyzyjne Republiki Austrii rozpoczęły faktyczny proces dochodzenia do pełnego członkostwa we Wspólnotach Europejskich, a zakończył wraz z dniem wejścia Austrii do Unii Europejskiej na początku $1995 \mathrm{roku}^{23}$.

Na pierwszym etapie relacji Austrii z kształtującym się wówczas procesem integracji europejskiej na pierwszy plan wysuwa się podział na dwa

21 Pojęcie (neo-)korporacjonizmu należy rozumieć jako zaistnienie ścisłej współpracy państwa z poszczególnymi grupami interesu, wśród których na szczególną uwagę zasługują związki zawodowe oraz zrzeszenia producentów. Szerzej patrz: P. Luif, $O n$ the Road to Brussels. The Political Dimension of Austria's, Finland's and Sweden's Accession to the European Union, Vienna 1995, s. $94 \mathrm{i} \mathrm{n.}$

${ }^{22} \mathrm{Na}$ temat austriackich idei dotyczących integracji starego kontynentu sięgających pierwszej połowy lat dwudziestych XX wieku patrz: M. Gehler, Österreichs Weg nach Bruessel bis zum Stellen der Beitrittsgesuche, w: Österreich und Europa. Beitraege zu Geschichte und Problematik der europaeischen Einigung um die Jahrtausendwende, Hrsg. R. Kriechbaumer, Wien 2000, s. 30 i n.

23 Por. J. Fidrmuc, K. Pichelmann, Austriackie doświadczenia wynikajace z przystapienia do Unii Europejskiej, w: Doświadczenia negocjacji akcesyjnych państw UE, red. S. Miklaszewski, Kraków 2000, s. 53-58. 
obozy pomiędzy państwami Europy Zachodniej, który dokonał się na przełomie lat pięćdziesiątych i sześćdziesiątych XX wieku, wraz z utworzeniem wyłącznie przez sześć państw członkowskich OEEC Europejskiej Wspólnoty Węgla i Stali, której regulacje weszły w życie w 1952 $\mathrm{roku}^{24}$. Niekorzystne dla austriackiej gospodarki rozwiązania odnośnie wymiany handlowej na obszarze sektora węglowego oraz stalowego, które były konsekwencją pozostania Austrii poza EWWiS skłoniły Wiedeń do zawarcia z „Szóstką” umowy taryfowej dotyczącej powyższych sektorów $^{25}$. Z kolei próba zneutralizowania negatywnych konsekwencji pozostawania poza nastawioną protekcjonistycznie na zewnątrz Europejską Wspólnotą Gospodarczą, którą podjęły państwa OEEC, które nie weszły do EWG na czele z Wielką Brytanią również nie przyniosły pożądanych rezultatów. Negocjacje Moudlinga zostały zakończone po ich zablokowaniu przez generała Charlesa de Gaulle'a w grudniu 1958 roku, a zatem bezpośrednio po uzyskaniu przez niego prezydentury nowo ukonstytuowanej Piątej Republiki Francji ${ }^{26}$.

Pozostanie Wielkiej Brytanii poza trzema utworzonymi w latach pięćdziesiątych Wspólnotami Europejskimi spowodowało w pierwszej kolejności powołanie alternatywnej organizacji - Europejskiego Stowarzyszenia Wolnego Handlu - EFTA, a następnie próby uzyskania przez Londyn członkostwa we Wspólnotach. Z perspektywy Austrii, która była współzałożycielem EFTA, szczególnie drugi krok Albionu nie mógł być postrzegany jako korzystny. Wieczysta neutralność usankcjonowana prawnie nie pozwalała Austrii myśleć o akcesji do organizacji, w której wszystkie sześć państw założycielskich było także członkami Paktu Północnoatlantyckiego. W związku z powyższym, ówczesny austriacki minister spraw zagranicznych, Bruno Kreisky 19 maja 1961 roku udzielił wypowiedzi, iż członkostwo Austrii w EWG pozostaje w sprzeczności z jej neutralnością, natomiast stowarzyszenie wydaje się możliwe. W konsekwencji pomimo wyrażanego niezadowolenia ze strony Moskwy ${ }^{27}$, Austria wraz z dwoma

${ }^{24}$ M. Scheich, Das Brechen eines politischen Tabus - Österreichs Weg in die EU, w: Österreich und Europa. Beitraege zu Geschichte und Problematik der europaeischen Einigung um die Jahrtausendwende, Hrsg. R. Kriechbaumer, Wien 2000, s. 17.

${ }^{25}$ G. Falkner, The Europeanisation ..., s. 2.

${ }^{26}$ Por. M. Scheich, Das Brechen ..., s. 17.

27 S. Hamel, ,Eine solche Sache wuerde der Neutraliaetspolitik ein Ende machen". Die österreichischen Integrationsbestrebungen 1961-1972, w: Österreich und die Europaeische Integration 1945-1993, Hrsg. M. Gehler, R. Steininger, Wien 1993, s. 58 . 
innymi państwami neutralnymi - Szwajcarią i Szwecją wystąpiły 15 grudnia 1961 roku o uzyskanie statusu stowarzyszenia ze Wspólnotami. W efekcie kolejnej zmiany sytuacji zewnętrznej, która została spowodowana blokadą akcesji Wielkiej Brytanii do EWG dokonaną przez Charlesa de Gaulle'a w styczniu 1963 roku zarówno Szwecja, jak też Szwajcaria wycofały swoje aplikacje, natomiast Austria postanowiła nie zmieniać obranej wcześniej strategii działania. Indywidualna postawa Wiednia (niem.: Alleingang Österreichs) nie przyniosła jednak efektów, czego powodem było weto Włoch ze względu na postępującą eskalację konfliktu odnośnie południowego Tyrolu ${ }^{28}$. Ostatecznie rozwiązanie kwestii Tyrolu w 1969 roku, jak również pomyślna akcesja Wielkiej Brytanii oraz Danii i Irlandii do EWG, po ustapieniu ze stanowiska prezydenta Francji Charlesa de Gaulle'a, doprowadziły do podpisania z EWG porozumienia o wolnym handlu (ang.: Free Trade Agreement - FTA) w 1972 roku $^{29}$.

Drugi etap charakteryzuje znaczny wzrost relacji handlowych między Austrią i Wspólnotami, przy jednoczesnym spadku powyższych z państwami członkowskimi odgrywającego coraz bardziej marginalną rolę ugrupowania EFTA. W konsekwencji realizacji porozumienia FTA w 1977 roku handel produktami przemysłowymi został zliberalizowany na obszarze EWG oraz EFTA, choć w stosunku do niektórych towarów wrażliwych bariery uwolniono ostatecznie dopiero w 1984 roku. Wynikiem zaistniałych wydarzeń były istotne zmiany na płaszczyźnie austriackiego eksportu. W 1978 roku już 46\% trafiało na rynek ,Szóstki”, podczas gdy państwa strefy EFTA były odbiorcami zaledwie 19\% eksportu Austrii $^{30}$.

Na etap trzeci składa się proces bezpośredniej drogi Austrii do uzyskania pełnego członkostwa w Unii Europejskiej z dniem 1 stycznia 1995 roku, przy czym wpływ na zmianę stanowiska Wiednia względem partycypacji we Wspólnotach Europejskich miały zarówno zewnętrzne, jak też wewnętrzne czynniki polityczne oraz kwestie natury ekonomicznej ${ }^{31}$.

28 F. Breuss, Austria's ..., s. 2.

29 Ibidem, s. 5.

30 J. Fidrmuc, K. Pichelmann, Austriackie ..., s. 56.

31 Por. G. Leitner, Der Weg nach Bruessel. Zur Geschichte des österreichischen EG-Beitrittsantrages vom 17. Juli 1989, w: Österreich und die Europaeische Integration 1945-1993, Hrsg. M. Gehler, R. Steininger, Wien 1993, s. 88. 


\subsection{Partie polityczne a członkostwo Austrii w Unii Europejskiej}

Jeszcze w 1945 roku Karol Renner odnowił Socjalistyczną Partię Austrii (niem.: Sozialistische Partei Österreichs - SPÖ), która dowodzona przez lewicowców zbliżonych do centrum, gotowa była do współpracy z odbudowanym ugrupowaniem chrześcijańsko-społecznym, noszącym nazwę Austriackiej Partii Ludowej (niem.: Österreichische Volksparei $\ddot{O} V P)$. Z kolei w ramach ÖVP przywództwo sprawowały osoby związane z ruchem oporu z okresu wojny, jak również ze związkami pracowniczymi oraz robotniczymi, co także na płaszczyźnie przekonań ideologicznych zbliżało powyższe ugrupowanie do socjalistów. Nie należy zatem dziwić się, iż pierwszy powojenny rząd w Austrii utworzony został w ramach koalicji obu wyżej wymienionych ugrupowań (tab. 4).

Tabela 4

Wyniki wyborów powszechnych w Austrii w latach 1945-1995 (w mandatach)

\begin{tabular}{||c|c|c|c|c|c|c||}
\hline & SPÖ* & ÖVP & FPÖ & KPÖ & $\mathbf{Z}$ & FL \\
\hline 1945 & 76 & 85 & - & 4 & - & - \\
\hline 1949 & 67 & 77 & 16 & 5 & - & - \\
\hline 1953 & 73 & 74 & 14 & 4 & - & - \\
\hline 1956 & 74 & 82 & 6 & 3 & - & - \\
\hline 1959 & 78 & 79 & 8 & - & - & - \\
\hline 1962 & 76 & 81 & 8 & - & - & - \\
\hline 1966 & 74 & 85 & 6 & - & - & - \\
\hline 1970 & 81 & 78 & 6 & - & - & - \\
\hline 1971 & 93 & 80 & 10 & - & - & - \\
\hline 1975 & 93 & 80 & 10 & - & - & - \\
\hline 1979 & 95 & 77 & 11 & - & - & - \\
\hline 1983 & 90 & 81 & 12 & - & - & - \\
\hline 1986 & 80 & 77 & 18 & - & 8 & - \\
\hline 1990 & 80 & 60 & 33 & - & 10 & - \\
\hline 1994 & 65 & 52 & 42 & - & 13 & 11 \\
\hline 1995 & 71 & 52 & 41 & - & 9 & 10 \\
\hline
\end{tabular}

* - SPÖ - Socjalistyczna Partia Austrii, ÖVP - Austriacka Partia Ludowa, KPÖ - Komunistyczna Partia Austrii, FPÖ - Wolnościowa Partia Austrii, Z - Zieloni, FL - Forum Liberalne.

Źródlo: P. Luif, Österreich, w: Europa-Handbuch, Hrsg. W. Weidenfeld, Bonn 1999, s. 185.

Trzecim najbardziej liczącym się ugrupowaniem politycznym po zakończeniu wojny była Komunistyczna Partia Austrii (niem.: Komunistische Partei Österreichs - KPÖ), której pozycja była szczególnie silna 
w radzieckiej strefie okupacyjnej Austrii. Przedstawiciele powyższych trzech partii obejmowali po zakończeniu drugiej wojny światowej stanowiska administracyjne na wszystkich szczeblach, a zatem zarówno w gminach, jak też w krajach ${ }^{32}$.

Obie główne siły polityczne - ÖVP i SPÖ - obrały proeuropejska opcje $^{33}$, przy czym w przypadku pierwszej z nich powyższa postawa przyjęta została znacznie wcześniej, bo już na początku lat siedemdziesiątych. Natomiast socjaliści, którzy w 1991 roku zmienili nazwę swojego ugrupowania na Socjaldemokratyczna Partia Austrii (niem.: Sozialdemokratische Partei Österreichs - SPÖ) - obawiając się między innymi utraty wpływów na scenie politycznej, co wynikałoby z ich punktu widzenia ze zmniejszenia sektora publicznego po akcesji, w ramach którego bardzo silną pozycję zajmowały związki zawodowe, które tradycyjnie powiązane były z Partią Socjalistyczną - opcję prointegracyjną zaakceptowali dopiero w drugiej połowie lat osiemdziesiątych, kiedy to stanowisko kanclerza objął przywódca SPÖ, Franz Vranitzky ${ }^{34}$.

Tabela 5

Prezydenci Republiki Austrii po drugiej wojnie światowej

\begin{tabular}{||l|c|c||}
\hline \multicolumn{1}{|c|}{ Prezydent } & Okres urzędowania & Partia \\
\hline Karl Renner & $1945-1950$ & SPÖ \\
\hline Theodor Körner & $1951-1957$ & SPÖ \\
\hline Adolf Schärf & $1957-1965$ & SPÖ \\
\hline Franz Jonas & $1965-1974$ & SPÖ \\
\hline Rudolf Kirchschläger & $1974-1986$ & SPÖ \\
\hline Kurt Waldheim & $1986-1992$ & ÖVP \\
\hline Thomas Klestil & $1992-2004$ & ÖVP \\
\hline Heinz Fischer & $2004-\ldots$ & SPÖ \\
\hline
\end{tabular}

Źródło: Opracowanie własne na podstawie: Austria: A Study in Modern Achievement, eds. J. Sweeney, J. Weidenholzer, Aldershot 1988.

Za najbardziej zdecydowanych zwolenników procesu integracji Austrii z Unią Europejską należy natomiast uznać członków odgrywającego

32 H. Wereszycki, Historia ..., s. 304.

33 Komunistyczna Partia Austrii zajmowała liczącą się pozycję w czasach, gdy proces integracji europejskiej dopiero się rozpoczynał, a udział w nim Austrii w zasadzie nie wchodził $\mathrm{w}$ grę.

34 Por. T. Ciszak, C. Herma, R. Hykawy, Rozszerzenie UE o kraje EFTA, „Biuletyn Analiz UKIE", nr 6, maj 2001, s. 83. 
mniej znaczącą rolę Forum Liberalnego (niem.: Liberales Forum), które odłączyło się od Partii Wolnościowej, kiedy w tej zapanowały nastroje nacjonalistyczne ${ }^{35}$. Natomiast przeciw integracji opowiadali się Zieloni (niem.: die Grünnen) oraz skrajnie prawicowa Partia Wolnościowa Austrii (niem.: Freiheitliche Partei Österreichs), która po objęciu władzy w jej strukturach przez Joerga Haidera prezentowała antyeuropejską postawę, choć ostatecznie jej przywódcy postanowili nie rekomendować swoim zwolennikom sposobu głosowania w referendum akcesyjnym ${ }^{36}$.

Tabela 6

Kanclerze oraz partie sprawujące rządy w Austrii po 1945 roku

\begin{tabular}{||c|c|c||}
\hline Okres urzędowania & Kanclerz & Partie sprawujące władze \\
\hline 1945 & Karl Renner (SPÖ) & SPÖ, ÖVP, KPÖ \\
\hline $1945-1949$ & Leopold Figl (ÖVP) & SPÖ, ÖVP, KPÖ* \\
\hline $1949-1953$ & Leopold Figl (ÖVP) & SPÖ, ÖVP \\
\hline $1953-1956$ & Julius Raab (ÖVP) & SPÖ, ÖVP \\
\hline $1956-1959$ & Julius Raab (ÖVP) & SPÖ, ÖVP \\
\hline $1959-1961$ & Alphons Gorbach (ÖVP) & SPÖ, ÖVP \\
\hline $1961-1964$ & Alphons Gorbach (ÖVP) & SPÖ, ÖVP \\
\hline $1964-1966$ & Josef Klaus (ÖVP) & SPÖ, ÖVP \\
\hline $1966-1970$ & Josef Klaus (ÖVP) & ÖVP \\
\hline $1970-1983$ & Bruno Kreisky (SPÖ) & SPÖ \\
\hline $1983-1986$ & Fred Sinowatz (SPÖ) & SPÖ, FPÖ \\
\hline $1986-1997$ & Franz Vranitzky (SPÖ) & SPÖ, ÖVP \\
\hline $1997-2000$ & Viktor Klima & SPÖ, ÖVP \\
\hline $2000-\ldots$ & Wolfgang Schüssel & ÖVP, FPÖ \\
\hline
\end{tabular}

* - Komunistyczna Partia Austrii opuściła rząd na znak protestu w stosunku do decyzji Austrii w kwestii uczestnictwa w Planie Marshalla.

Źródło: Austria: A Study in Modern Achievement, eds. J. Sweeney, J. Weidenholzer, Aldershot 1988, s. 278-279; online: http://www.jusundpolitik.at/regierung/seit1945.html, 15.03.2003.

4.2. Przebieg negocjacji akcesyjnych

Przełom lat osiemdziesiątych i dziewięćdziesiątych XX wieku przyniósł sytuację, która pozwoliła państwom EFTA pozostającym poza

35 M. Leska, A. Ostrowska, Drogi ..., s. 11.

36 T. Ciszak, C. Herma, R. Hykawy, Rozszerzenie ..., s. 107. 
Wspólnotami coraz realniej myśleć o członkostwie w WE. Jednocześnie na początku 1992 roku podpisany został Traktat z Maastricht, który w istotny sposób zmieniał dotychczasową specyfikę Wspólnot Europejskich. Z perspektywy państw neutralnych szczególnie włączenie do wspólnotowej struktury projektu utworzenia Wspólnej Polityki Zagranicznej i Bezpieczeństwa - WPZB oraz plan realizacji Unii Gospodarczej i Walutowej - UGiW prezentowały się jako niezmiernie istotne kwestie, ponieważ w bezpośredni sposób wpływały na zmiany o zasadniczym charakterze dotyczące kwestii utrzymania statusu neutralności po ewentualnej akcesji (WPZB) oraz istotnego ograniczenia suwerenności na płaszczyźnie polityki gospodarczej (UGiW). Andreas Bieler słusznie postuluje, iż mogły one zatem w zasadniczy sposób wpłynąć na zmianę postawy poszczególnych ugrupowań prointegracyjnych w krajach EFTA. Autor dodaje jednak, iż zjawisko tego rodzaju nie miało miejsca ${ }^{37}$. Natomiast z określonej perspektywy Austria, jak również pozostałe aplikujące o pełne członkostwo w UE kraje EFTA, w zasadzie mogła być zadowolona z problemów, które Brukseli przysporzył proces ratyfikacji Traktatu z Maastricht ${ }^{38}$. Powyższa nieco paradoksalna konstatacja wynika z przesłanki, iż z perspektywy skuteczności politycznej Unia Europejska nie mogła pozwolić sobie na kolejną porażkę. Drugim czynnikiem, który w istotny sposób wpłynął na późniejszy proces rzeczywistych negocjacji akcesyjnych było utworzenie Europejskiego Obszaru Gospodarczego - EOG (ang.: European Economic Area-EEA), który oznaczał istotne zbliżenie się państw EFTA do państw EWG, choć ograniczało się ono w zasadzie do płaszczyzny ekonomicznej. Formalne negocjacje rozpoczęły się w czerwcu 1990 roku, przy czym odrzucenie przez społeczeństwo Szwajcarii w referendum uzgodnionych przez reprezentantów państw WE i EFTA rozwiązań ${ }^{39}$

37 A. Bieler, Globalisation and Enlargement of the European Union. Austrian and Swedish Social Forces in the Struggle over Membership, London-New York 2000, s. 116.

382 czerwca 1992 roku 50,7\% społeczeństwa Danii opowiedziało się w referendum przeciwko udziałowi swojego kraju w Traktacie z Maastricht. Trzy miesiące później (20.09.1992) zaledwie 51,05\% Francuzów zaakceptowało w referendum warunki Traktatu. Po decyzji Rady Europejskiej w Edynburgu (11-12 grudnia 1992) zezwalającej Danii na pozostanie poza jednolitym systemem walutowym oraz projektowanej na przyszłość wspólnej polityce obronnej, 18 kwietnia 1993 roku Duńczycy zaakceptowali $(56,8 \% \mathrm{za}) \mathrm{w}$ drugim referendum postanowienia Traktatu z Maastricht.

${ }^{39}$ Szwajcarskie społeczeństwo 6 grudnia 1992 roku minimalną większością $(50,3 \%)$ pozostawiło swoje państwo poza strukturami EOG. 
w praktyce oznaczało zwłokę w implementacji porozumienia, które weszło w życie $\mathrm{z}$ dniem 1 stycznia 1994 roku $^{40}$.

W momencie ogłoszenia w styczniu 1989 roku przez Jacquesa Delorsa propozycji utworzenia organizacji EOG, Austria była już zdecydowana na pełną partycypację we Wspólnotach Europejskich. W konsekwencji jako pierwsze państwo z grupy krajów pozostających w EFTA u schyłku rywalizacji zimnowojennej podjęło decyzję o ubieganiu się o pełne członkostwo we Wspólnotach Europejskich.

Po dwóch latach debaty dotyczącej akcesji, 17 lipca 1989 roku federalny minister spraw zagranicznych Austrii, Alois Mock wręczył Rolandowi Dumas, ministrowi spraw zagranicznych Francji, która wówczas sprawowała prezydencję w WE wniosek o przyjęcie Austrii do Wspólnot ${ }^{41}$. Należy zatem podkreślić, iż w rezultacie Austria przyjęła dwutorową strategię, która polegała na jednoczesnym uczestnictwie w pertraktacjach na temat utworzenia EOG oraz na kontynuowaniu starań o rozpoczęcie negocjacji o pełne członkostwo w $\mathrm{WE}^{42}$. Powody takiej strategii obrazowo oddał były szef misji austriackiej przy UE, ambasador Wolfgang Wolte, konstatując, iż z perspektywy zamierzonych celów rządu Austrii EOG „nie był ani rybą, ani mięsem" "43.

W odpowiedzi na austriacką aplikację Rada już 28 lipca 1989 roku wszczęła procedurę akcesyjną, występując z wnioskiem do Komisji o sporządzenie Opinii (fr.: Avis). Niezależnie od kroków zmierzających do sfinalizowania porozumienia o EOG rozpoczął się zatem również proces włączania Austrii do WE. Zależność pomiędzy powyższymi procesami w dużym stopniu przyczyniła się następnie do dynamicznego postępu w początkowej fazie negocjacji akcesyjnych do WE, co wynikało z szeregu obszarów, które zostały wcześniej wynegocjowane podczas konstruowania Europejskiego Obszaru Gospodarczego (tab. 7).

W przygotowywanej w ciąu dwóch lat Opinii, Komisja podkreśliła wysoki poziom zintegrowania austriackiej gospodarki w stosunku do rynku WE, jej dynamiczny wzrost w latach osiemdziesiątych, jak również

40 C. Preston, EFTA, the EU and the EEA, w: The 1995 Enlargement of the European Union, ed. J. Redmond, Aldershot-Vermont 1997, s. 28.

41 V. M. Reyes, Reguly ..., s. 149.

42 C. Preston, Enlargement \& Integration in the European Union, Routledge, London-New York 1997, s. 93.

43 Cytat podaję za: V. M. Reyes, Reguty ..., s. 149. 
stabilność waluty austriackiej ${ }^{44}$. Wyszczególniła również dwa potencjalne obszary problemowe na polu gospodarki - rolnictwo oraz politykę transportową. Z kolei na płaszczyźnie politycznej najwięcej obaw Komisji wzbudził status neutralności środkowoeuropejskiego państwa, choć jednocześnie Opinia prezentuje pogląd, iż powyższa kwestia nie powinna okazać się przeszkodą uniemożliwiającą proces akcesji ${ }^{45}$.

Tabela 7

Rozdziały negocjacji akcesyjnych w relacji do obszarów wynegocjowanych w ramach EOG

\begin{tabular}{|c|c|c|}
\hline Rozdziały & Zawartość & $\begin{array}{l}\text { Stopień } \\
\text { trudności }\end{array}$ \\
\hline 1 & 2 & 3 \\
\hline \multirow{11}{*}{$\begin{array}{l}\text { Rozdziały prawie w całości } \\
\text { wynegocjowane w ramach } \\
\text { EOG }\end{array}$} & 1. Swobodny przepływ towarów & $* *$ \\
\hline & $\begin{array}{l}\text { 2. Swoboda świadczenia usług oraz prawo } \\
\text { zakładania spółek }\end{array}$ & $*$ \\
\hline & 3. Swobodny przepływ pracowników & $*$ \\
\hline & 4. Swobodny przepływ kapitału & $*$ \\
\hline & 5. Transport & $* * *(a)$ \\
\hline & 6. Konkurencja & $* * *(b)$ \\
\hline & 7. Ochrona zdrowia oraz konsumentów & $*$ \\
\hline & 8. Badania naukowe oraz technologie & $*$ \\
\hline & 9. Edukacja i dokształcanie & $*$ \\
\hline & 10. Statystyka & $*$ \\
\hline & 11. Prawo spółek & $*$ \\
\hline \multirow{5}{*}{$\begin{array}{l}\text { Rozdziały częściowo objęte } \\
\text { przez EOG }\end{array}$} & 12. Polityka społeczna & $*$ \\
\hline & 13. Ochrona środowiska & $* *$ \\
\hline & 14. Energia & $* * *(\mathrm{c})$ \\
\hline & 15. Rolnictwo & $* * *$ \\
\hline & 16. Rybołówstwo & $* * *$ \\
\hline \multirow{6}{*}{$\begin{array}{l}\text { Rozdziały nie objęte przez } \\
\text { EOG a znajdujące się w trak- } \\
\text { tatach wspólnotowych }\end{array}$} & 17. Unia celna & $*$ \\
\hline & 18. Zewnętrzne stosunki handlowe & $*$ \\
\hline & 19. Mechanizmy strukturalne & $* * *$ \\
\hline & 20. Polityka regionalna & $* * *$ \\
\hline & 21. Polityka przemysłowa & $*$ \\
\hline & 22. Polityka podatkowa & $* *$ \\
\hline
\end{tabular}

44 Szerzej patrz: L. Neal, D. Barbezat, The Economics of the European Union and the Economies of Europe, New York \& Oxford 1998, s. 320 i n.

45 European Commision, Opinion on Austria's Application for Membership, „Bulletin of the European Communities, Supplement 4/92. 


\begin{tabular}{||l|l|c||}
\hline \hline \multicolumn{1}{|c|}{1} & \multicolumn{1}{|c|}{2} & 3 \\
\hline \multirow{2}{*}{$\begin{array}{l}\text { Rozdziały dotyczące dodat- } \\
\text { kowych kwestii objętych } \\
\text { traktatem z Maastricht }\end{array}$} & 23. Polityka gospodarcza i monetarna & $*$ \\
\cline { 2 - 3 } & 24 . Polityka zagraniczna i bezpieczeństwa & $*$ \\
\cline { 2 - 3 } & 25. Sprawiedliwość i sprawy wewnętrzne & $*$ \\
\cline { 2 - 3 } & 26. Inne zarządzenia & $*$ \\
\hline \multirow{2}{*}{$\begin{array}{l}\text { Rozdziały ogólne dotyczące } \\
\text { bezpośrednio procesu rozsze- } \\
\text { rzenia }\end{array}$} & 27. Kwestie finansowe i budżetowe & $* *$ \\
\cline { 2 - 3 } & 28. Instytucje & $*$ \\
\cline { 2 - 3 } & 29. Inne & $*$ \\
\hline
\end{tabular}

* - nieskomplikowana kwestia; ** - kwestia skomplikowana; *** - bardzo trudna kwestia zakończona rozwiązaniem kompromisowym o charakterze politycznym; (a) - dotyczy wyłącznie alpejskiego tranzytu w Austrii; (b) - dotyczy wyłącznie pomocy państwowej; (c) - dotyczy wyłącznie kwestii wydobycia lub handlu ropą naftową w Norwegii.

Źródło: Opracowanie własne na podstawie: F. Granell, The European Union’s Enlargement Negotiations with Austria, Finland, Norway and Sweden, „Journal of Common Market Studies”, Vol. 33, No. 1, March 1995, s. 122; P. Luif, On the Road to Brussels: the Political Dimension of Austria's, Finland's and Sweden's Accession to the European Union, Vienna 1995, s. 308; P. Nicolaides, A. Close, Accession to the European Union: The Ultimate Bargain, w: The Political Economy of European Integration, Maastricht 1995, s. 300; V. M. Reyes, Reguly gry czyli o negocjacjach akcesyjnych i taczeniu się Europy, Warszawa 2000, s. 154.

Oficjalne negocjacje akcesyjne rozpoczęły się 1 lutego 1993 roku. Wcześniej we wspólnym raporcie przedstawionym 21 stycznia 1993 roku rządowi, kanclerz Vranitzky oraz minister spraw zagranicznych i jednocześnie główny negocjator Mock zakreślili pozycje negocjacyjne Austrii.

Najważniejsze kwestie powyższego dokumentu obejmowały:

- pragnienie Austrii by wpłacać niskie stawki do wspólnotowego budżetu oraz by uzyskiwać korzyści finansowe z tytułu funduszy strukturalnych,

- zachowanie statusu neutralności w relacji z planowaną WPZB,

- zachowanie wyższych niż wspólnotowe standardów ekologicznych oraz socjalnych,

- kontynuację po akcesji ustaleń zawartych w 1991 roku w Umowie Tranzytowej,

- chęć uzyskania okresu przejściowego w celu stopniowego dostosowania się do regulacji Wspólnej Polityki Rolnej,

- kwestię regulacji odnośnie możliwości zakupu przez obywateli państw Wspólnoty tzw. drugich domów ${ }^{46}$.

Jednocześnie pomimo relatywnie małej ilości kwestii spornych pomiędzy Austrią i Wspólnotami w zasadzie wszystkie wyszczególnione

46 A. Bieler, Globalisation ..., s. 92. 
powyżej obszary stały się przedmiotem silnych kontrowersji w trakcie procesu negocjacyjnego ${ }^{47}$.

W trakcie negocjacji właściwych odbyło się 9 rund negocjacyjnych na szczeblu ministrów oraz 13 na szczeblu ich zastępców. W pierwszym półroczu procesu zamknięto pertraktacje w zakresie ochrony zdrowia i konsumenta, edukacji, prawa spółek oraz polityki społecznej. Natomiast najdłużej trwały rozmowy w ramach swobodnego świadczenia usług, polityki konkurencji, badań i technologii informacyjnych, unii celnej stosunków zewnętrznych, transportu oraz rolnictwa ${ }^{48}$, przy czym po okresie pewnego zastoju pod koniec 1993 roku, zintensyfikowanie tempa negocjacji nastapiło pomiędzy styczniem a marcem 1994 roku. Presja by zakończyć negocjacje w zaplanowanym terminie spowodowana była w dużej mierze kończącą się kadencją Parlamentu Europejskiego, dla którego - przy założeniu zakończenia rokowań w terminie - pozostawało i tak niewiele czasu na akceptację postanowień ${ }^{49}$. Ostateczne porozumienie osiągnięto 1 marca 1994 roku. Na czwartą fazę składa się debata w obrębie „Dwunastki” odnośnie instytucjonalnych konsekwencji rozszerzenia. Rozbieżności dotyczyły przede wszystkim niezbędnej do zablokowania liczby głosów w Radzie UE podczas głosowania większością kwalifikowaną. Tymczasowe porozumienie, które nazwano kompromisem z Ioanniny od nazwy miejscowości, w której został zawarty przewidywał zwiększenie liczby blokujących głosów z dotychczasowych 23 do 27 po rozszerzeniu. Po opowiedzeniu się w maju 1994 roku w Parlamencie Europejskim za procesem rozszerzenia przyszedł czas na ratyfikację układu w aplikujących krajach ${ }^{50}$.

4.3. Wynik negocjacji akcesyjnych oraz zestawienie okresów przejściowych

Traktat o przystapieniu Królestwa Norwegii, Republiki Austrii, Republiki Finlandii oraz Królestwa Szwecji do Unii Europejskiej (TP $)^{51}$ zawie-

47 F. Granell, The First Enlargement Negotiations of the EU, w: The 1995 Enlargement of the European Union, ed. J. Redmond, Aldershot 1997, s. 53 i n.

48 T. Ciszak, C. Herma, R. Hykawy, Rozszerzenie ..., s. 93.

49 S. Konopacki, Przystapienie Szwecji do Unii Europejskiej, „Studia Europejskie" 2001, nr 2, s. 88.

50 L. Miles, Sweden and European Integration, Aldershot-Brookfield 1997, s. 234.

51 Dokumenty dotyczace przystapienia do Unii Europejskiej Austrii, Finlandii i Szwecji, red. J. Plaňavová-Latanowicz, CEUW, t. 3, Warszawa 1998. 
ra przepisy własne, Akt dotyczący warunków przystąpienia Republiki Austrii, Republiki Finlandii oraz Królestwa Szwecji do Unii Europejskiej, jak również dziewiętnaście załączników oraz dziesięć protokołów. Należy także wspomnieć, iż ze względu na negatywny wynik referendum ogólnonarodowego dotyczącego akcesji do UE w Norwegii usunięto z niego trzydzieści sześć artykułów Aktu, cztery załączniki oraz jeden protokó $1^{52}$. We wspólnym dla Austrii, Finlandii i Szwecji dokumencie na omówienie przepisów przejściowych ${ }^{53}$ poświęcona jest część czwarta Aktu, przy czym postanowienia instytucjonalne omówione są w Tytule I części czwartej wspólnie dla obu państw, natomiast osobne tytuły dla trzech państw poświęcono pozostałym przepisom przejściowym ${ }^{54}$. W przypadku Austrii było to pięć rozdziałów:

1. Swobodny przepływ towarów (art. 69 TP),

2. Swobodny przepływ pracowników, usług i kapitałów (art. 70 TP),

3. Polityka konkurencji (art. 71-72 TP),

4. Stosunki zewnętrzne i unia celna (art. 73-78 TP),

5. Postanowienia finansowe i budżetowe (art. 79-83 TP).

52 J. Plaňavová-Latanowicz, Wprowadzenie, w: Dokumenty dotyczqce przystapienia do Unii Europejskiej Austrii, Finlandii i Szwecji, red. J. Plaňavová-Latanowicz, CEUW, t. 3, Warszawa 1998, s. 19.

53 Na uwagę zasługują słowa Doroty Olejniczak dotyczące problemów związanych z dokonaniem właściwego podziału ustanowionych przepisów przejściowych: „Przepisy normujące okresy przejściowe można uporządkować na dwa sposoby. Pierwszy podział dotyczy czasu trwania okresu przejściowego. Jedne z przepisów Traktatów określają od jakiej daty zaczną obowiązywać konkretne wspólnotowe akty prawne. Inne wyznaczają końcowy termin stosowania pewnych własnych regulacji lub przyjęcia regulacji wspólnotowych. Oznacza to, że wcześniejsze dostosowanie prawa krajowego do wspólnotowego jest dopuszczalne, ale niekonieczne. Byle by nie nastąpiło później niż w terminie określonym w Traktacie o przystąpieniu. Drugi podział może dotyczyć dziedzin prawa, których dotyczą okresy przejściowe. W zasadzie starano się klasyfikować je według podziału występującego w Traktacie Rzymskim (swobodny przepływ towarów, usług, kapitałów i osób, ochrona środowiska, rybołówstwo, rolnictwo itp.). Niemniej konkretne przepisy tematycznie ze sobą powiązane są bardzo porozrzucane po całym Traktacie i licznych doń aneksach". D. Olejniczak, $A u$ stria, w: Okresy przejściowe w Traktatach o przystapieniu do Europejskiej (wybrane przykłady: Hiszpania, Portugalia, Austria, Finlandia, Szwecja), Zespół Integracji Europejskiej (opracowanie zbiorowe), Biuro Studiów i Ekspertyz, Raport nr 145/1999.

54 Postanowienia instytucjonalne zawarte są w Tytule pierwszym, natomiast przepisy przejściowe dotyczące Austrii umieszczono w Tytule III, Finlandii w Tytule IV, a Szwecji w Tytule V. Powyższa numeracja wynika z faktu, iż Tytuł II został uchylony artykułem 3 Decyzji 95/1/WE, Euratom, EWWiS. 
Ad 1) Zawarte w art. 69 wyłączenie na okres czterech lat w zakresie swobodnego przepływu towarów odnośnie ograniczeń w handlu i używaniu poszczególnych niebezpiecznych substancji i preparatów wynikało $\mathrm{z}$ różnic $\mathrm{w}$ regulacjach austriackich i wspólnotowych. W pierwszym przypadku oznaczenia substancji szkodliwych odbywało się indywidualnie i z tego względu nie obejmowało niektórych substancji i preparatów, które w ramach prawa wspólnotowego podlegają zakazowi używania o charakterze kompleksowym. Dodatkowo Aneks XV zezwalał Austrii na utrzymanie do 1 października 1995 roku przepisów dotyczących emisji zanieczyszczeń z pewnych typów samochodów.

Ad 2) Na obszarze swobodnego przepływu osób, usług i kapitału, art. 70 TP pozwalał Austrii przez pięć lat zachować wcześniejsze przepisy odnośnie drugiego miejsca zamieszkania. Natomiast na podstawie Aneksu XV do Aktu o przystąpieniu przez cztery lata po akcesji Austria mogła nie stosować się do regulacji wspólnotowych dotyczących wzajemnego uznawania dyplomów oraz certyfikatów.

Ad 3) Okresy przejściowe w zakresie polityki konkurencji uregulowane zostały w art. 71 i 72, przy czym pierwszy z nich odnosił się do obowiązku państw członkowskich likwidowania monopoli państwowych. W szczególności kwestia dotyczyła obowiązku stopniowego - w okresie trzech lat po przystapieniu - odchodzenia od tego rodzaju austriackich regulacji odnośnie handlu tytoniem. Austria została także zobowiązana, by w ciagu roku po akcesji dokonać zmiany przepisów odnośnie handlu detalicznego. Natomiast art. 72 ustanawiał roczny okres przejściowy na dostosowanie w zakresie obejmującym regulacje handlu produktami spirytusowymi.

Ad 4) W odniesieniu do obszaru stosunków zewnętrznych i unii celnej uregulowane zostały okresy obowiązywania umów, które Austria zawarła przed przystąpieniem do Unii Europejskiej, jak również zawarte zostały daty, które szczegółowo ukazują kiedy umowy zawarte przez Wspólnotę przed rozszerzeniem staną się obowiązujące dla Austrii.

Ad 5) Na podstawie regulacji obejmujących kwestie finansowe oraz budżetowe Austria w okresie czterech lat po przystapieniu do UE uzyskiwać będzie kwoty finansowe ze wspólnotowego budżetu, przy czym co roku będzie ona się zmniejszać. Art. 81 stanowi, iż Austria otrzyma do końca 1998 roku następujące kwoty:

„[...] - w 1995 roku - 583 milionów ECU;

- w 1996 roku - 106 milionów ECU;

- w 1997 roku - 71 milionów ECU; 


\section{- w 1998 roku - 35 milionów ECU"55.}

Dodatkowo Wspólnota zobowiązała się do pokrycia zobowiązań finansowych wynikających z członkostwa Austrii w EOG ${ }^{56}$.

Chociaż obszar rolnictwa uregulowany został w osobnym, wspólnym dla wszystkich państw kandydujących tytule części czwartej TP (Tytuł VI), nie oznacza to, iż kwestie dotyczące powyższego obszaru posiadały jednakowe regulacje dla wszystkich nowych państw członkowskich, co wynika między innymi z faktu, iż wiele poszczególnych zagadnień dotyczących obszaru rolnictwa uregulowano również poza Aktem, przy czym postanowienia zamieszczone w ramach Aktu odnoszą się w zasadzie wyłącznie do możliwości udzielania pomocy państwowej rolnikom. Powyższe, trwające pięć lat zwolnienie od reguł Wspólnej Polityki Rolnej wynikało w dużym stopniu z faktu, iż w okresie przed akcesją Austrii do UE austriaccy rolnicy mieli zapewniony wyższy - od 10 do $40 \%$ - poziom cen gwarantowanych niż obowiązujący w ramach $\mathrm{WPR}^{57}$. Należy jednocześnie podkreślić, iż możliwość udzielenia państwowej pomocy austriackim rolnikom obwarowana była relatywnie długą listą szczegółowych warunków.

Natomiast wyłączenia zawarte w Aneksie XV do Aktu odnosiły się do szeregu niejednokrotnie znacznie różniących się od siebie kwestii, wśród których wymienić należy między innymi: odroczenie stosowania wspólnej taryfy celnej, wspólnych standardów jakościowych, jak też zasad opisu i prezentacji szczegółowo wskazanych produktów rolnych.

Należy także zwrócić uwagę na okresy przejściowe, które nie zostały zawarte w Akcie tylko w poszczególnych aneksach i protokołach dołączonych do Aktu, przy czym - jak stwierdza D. Olejniczak - powyższe „wyłączenia zostały sformułowane w sposób zróżnicowany jeśli chodzi o stopień ogólności - mogą dotyczyć określonych dziedzin, całych aktów prawnych (dyrektyw czy rozporządzeń), ściśle wskazanych artykułów tych aktów prawnych, albo nawet dotyczyć kwestii bardzo szczegółowych - np. specyficznych produktów. W Akcie zastosowano też różne metody wyznaczenia okresów przejściowych" ${ }^{\text {"58 }}$. Obejmowały one przy

55 Patrz: Dokumenty dotyczace przystapienia do Unii Europejskiej Austrii ..., s. 54.

56 Austria pozostawała w Europejskim Obszarze Gospodarczym po akcesji do UE, przy czym jeżeli przed przystąpieniem do UE pozostawała po stronie państw EFTA, po akcesji znajdowała się po stronie państw Unii Europejskiej.

57 Por. T. Ciszak, C. Herma, R. Hykawy, Rozszerzenie ..., s. 101.

58 D. Olejniczak, Austria ... 
tym kwestię ujednolicenia w dziedzinie statystyki, szczegółowego aspektu regulacji dotyczącej zasady równego traktowania kobiet i mężczyzn w zakresie dostępu do zatrudnienia w ramach polityki społecznej, konkretnych wyjątków w odniesieniu do wspólnotowej regulacji podatkowej (Aneks XV).

Jedna $\mathrm{z}$ trudniejszych kwestii $\mathrm{w}$ trakcie procesu negocjacyjnego - obszar transportu - uregulowana została w ramach Protokołu 9. Przewidywał on utrzymanie w mocy postanowień zawartej w październiku 1991 roku Umowy Tranzytowej, przy jednoczesnym skróceniu zasięgu jej obowiązywania o rok, a zatem do końca 2003 roku. Odnośnie dostosowania przez Austrię stosowanego w UE systemu opłat drogowych uzgodniony został dwuletni okres przejściowy. W innym szczególnie wrażliwym obszarze negocjacyjnym, który obejmował kwestie ochrony środowiska, Austria - podobnie jak pozostali kandydaci - uzyskała możliwość utrzymania wyższych niż obowiązujące w UE standardów w okresie do końca $1998 \mathrm{roku}^{59}$.

\subsection{Strategia informacyjna oraz debata na temat akcesji Austrii do Unii Europejskiej}

Strategia dotycząca kampanii informacyjnej odnośnie wejścia Austrii do Unii Europejskiej zawierała zasadniczo dwie części. Z jednej strony był to proces docierania do społeczeństwa austriackiego z informacjami na temat procesu integracyjnego, natomiast druga część obejmowała przekonanie Austriaków o korzyściach płynących z oddania przez nich podczas plebiscytu ogólnonarodowego odnośnie akcesji ich państwa głosu na „tak”. Za większość części odnoszącej się do udzielania informacji odnośnie Unii Europejskiej odpowiedzialni byli urzędnicy administracji publicznej. Kontaktami z poszczególnymi grupami interesu zajmowała się przy tym grupa konsultacyjna przy Urzędzie Kanclerskim, natomiast informacje w stosunku do obywateli na płaszczyźnie indywidualnej udzielali pracownicy austriackiej służby cywilnej, którzy jako grupa zawodowa - co z perspektywy kraju Europy Środkowo-Wschodniej szczególnie warte podkreślenia - cieszą się wśród Austriaków wysokim autorytetem ${ }^{60}$.

59 T. Ciszak, C. Herma, R. Hykawy, Rozszerzenie ..., s. 98.

60 V. M. Reyes, Reguly ..., s. 159. 
Natomiast część kampanii skierowana na uzyskanie jak najwyższego poziomu poparcia dla integracji została zlecona PR-owskiej organizacji zewnętrznej - utworzonemu jeszcze w 1991 roku Austriackiemu Towarzystwu na Rzecz Polityki Europejskiej (niem.: Österreichische Gesellschaft fuer Europapolitik - ÖGE), którą kierował Gerhard Bauer ${ }^{61}$. Podstawowym założeniem przedsiębranych działań było ukazanie korzyści płynących z procesu integracji w celu podwyższenia nie najbardziej optymistycznie wyglądającego jeszcze na przełomie 1991 i 1992 roku poziomu identyfikacji Austriaków z Europą (tab. 8).

Tabela 8

Stopień identyfikacji z Europą wybranych społeczeństw europejskich

\begin{tabular}{||l|c|}
\hline \multicolumn{1}{||c|}{ "Czy czujesz się obywatelem własnego kraju, a jednocześnie Europy?” } \\
\hline PANTWA & ODPOWIEDZI NA „TAK” \\
\hline Szwajcaria & $57 \%$ \\
\hline Wielka Brytania & $31 \%$ \\
\hline Austria & $28 \%$ \\
\hline Średnia w krajach członkowskich WE & $16 \%$ \\
\hline \hline
\end{tabular}

Źródlo: M. Leska, A. Ostrowska, Drogi do Unii Europejskiej. Narodowe strategie informacyjne, Warszawa 1998, s. 12.

Autorzy strategii wyodrębnili poszczególne grupy docelowe, w skład których wchodziły zarówno grupy zawodowe, jak też środowiskowe:

- kobiety, zwłaszcza matki, które postrzegałyby wybór w kontekście przyszłości swoich dzieci,

- ludzie starsi, wśród których naturalną reakcją może okazać się obawa przed zmianami,

- rolnicy, którzy mogli odnosić się z niechęcią w stosunku do zmian w ramach dostosowania powyższego sektora do Wspólnej Polityki Rolnej UE,

- mali i średni przedsiębiorcy, u których obawy mogły powstawać na bazie zwiększenia konkurencji po akcesji,

- robotnicy, którzy mogli obawiać się o utratę pracy,

- nauczyciele, mogący spodziewać się wzrostu konkurencji ze strony nauczycieli niemieckich.

${ }^{61}$ Negocjacje akcesyjne. Wnioski z doświadczeń Austrii, Finlandii, Norwegii i Szwecji, Natolin 1999, s. 32. 
Na podstawie powyższego podziału opracowano skierowane do poszczególnych grup broszury informacyjne. Należy przy tym podkreślić, iż od początku akcja skierowana była przede wszystkim do niezdecydowanej części społeczeństwa austriackiego, która w połowie 1992 roku wynosiła aż 75\% mających prawo wziąć udział w referendum ${ }^{62}$. Przykładowo, bezpośrednią akcją ÖGE zostali objęci taksówkarze - co wynikało ze specyfiki ich zawo$\mathrm{du}$, oraz gospodynie domowe - które były jedną z grup najbardziej przeciwnych integracji. Na uwagę zasługuje także szczegółowa analiza argumentów przeciw integracji na podstawie wypowiedzi antyeuropejskiego dziennika „Taeglich Alles”, na podstawie których następnie wymyślano dowcipy, mające na celu podkreślenie trywialność argumentacji przeciw akcesyjnej ${ }^{63}$.

Nie bez znaczenia dla kształtu strategii informacyjnej pozostaje fakt, iż na czele ugrupowań stojących po stronie przystąpienia Austrii do Wspólnot Europejskich znajdowały się dwie rządzące wówczas partie. Prointegracyjne argumenty, które prezentowały, w znacznym stopniu różniły się od siebie. ÖVP koncentrowała się na kwestii zwiększenia bezpieczeństwa oraz powiększenia wpływu na decyzje na arenie międzynarodowej Austrii w przypadku przystapienia, natomiast SPÖ - choć również brało pod uwagę korzyści podkreślane przez Ludowców - przykładało większą wagę do pozytywnych konsekwencji akcesji na płaszczyźnie społeczno-gospodarczej ${ }^{64}$.

Z kolei przeciwstawiający się akcesji przywódca FPÖ - Joerg Haider, z jednej strony podkreślał, iż nie jest przeciwny akcesji jako takiej, lecz warunkom wynegocjowanym przez koalicję rządzącą, z drugiej natomiast w znacznej mierze przyczynił się do obniżenia poziomu debaty na płaszczyźnie merytorycznej, używając argumentów o silnie defetystycznej zawartości, nakreślając wizję konsekwencji członkostwa w postaci napływu fali masowej imigracji do Austrii, pojawienia się korupcji o mafijnym zabarwieniu, czy też znacznego zwiększenia poziomu bezrobocia. Na szczególną uwagę zasługują także wypowiedzi o całkowicie populistycznym charakterze, wśród których prominentnym przykładem jest utrzymywanie, iż czekolada w Unii Europejskiej produkowana jest na bazie zainfekowanego wszami jogurtu ${ }^{65}$.

Interesująco ukazują się kontrowersje co do oceny austriackiej strategii informacyjnej. Z jednej strony często można spotkać się z pozytywną

\footnotetext{
62 M. Leska, A. Ostrowska, Drogi ..., s. 11-14.

63 V. M. Reyes, Reguty ..., s. 160.

64 D. Phinnemore, Austria ..., s. 69.

65 Ibidem.
} 
opinią na jej temat: „Stopień rozpoznania populacji, subtelność argumentów oraz wymyślność kanałów komunikacji każe uznać kampanię austriacką za najbardziej profesjonalną i kompleksowa, jaką do tej pory przeprowadzono $\mathrm{w}$ ramach procesu negocjacyjnego integracji z Unią Europejską. Wyniki badań socjologicznych, jak i końcowy wynik referendum potwierdzają tę opinię"66. Trudno nie zgodzić się z powyższą tezą, jeżeli uznamy, iż pozytywny rezultat referendum pełni rolę ostatecznego miernika skuteczności działań informacyjnych. Jeżeli natomiast skuteczność przekazu rozciagniemy również na okres bezpośrednio po przystąpieniu Austrii do Unii Europejskiej, sytuacja zaczyna być znacznie bardziej skomplikowana. I w tym przypadku najczęściej podawana przyczyna spadku poparcia dla UE wśród Austriaków w zasadzie bezpośrednio po akcesji o $30 \%$ to zaniechanie kampanii informacyjnej po osiągnięciu zadowalającego rezultatu w referendum przystapieniowym ${ }^{67}$. Wydaje się natomiast, iż podstawową przyczyną bardzo rozpowszechnionego wśród społeczeństwa austriackiego zawodu w stosunku do wejścia ich kraju w struktury wspólnotowe był zbyt daleko idący optymizm zmieszany ze zbyt daleko idącymi obietnicami w okresie przedakcesyjnym. Fritz Breuss konstatuje: „Analiza motywacji decyzji w referendum z 12 kwietnia 1994 ukazała, iż większość głosowała za członkostwem ze względu na oczekiwania uzyskania korzyści wynikających z integracji z większym rynkiem. W krótkim okresie powyższe oczekiwania nie spełniły się. Przyczynę frustracji populacji Austrii odnośnie członkostwa w UE w półtora roku po akcesji do UE można znaleźć w mieszance rządowej propagandy oraz naukowych szacunków dotyczących efektów integracji”68.

Inną bardzo istotną konsekwencją kampanii informacyjnej, w formie w jakiej prowadzona była ona w Austrii, był mocno niezadowalający poziom argumentów, których używano w trakcie debaty. Zarówno obóz prointegracyjny, jak również przeciwnicy akcesji szczególnie w ostatnim etapie poprzedzającym referendum używali pozamerytorycznych, opartych na emocjach argumentów, przy czym miały one dodatkowo ściśle jednostronny charakter, co oznaczało iż w czarno-białych barwach obóz „tak” odmalowywał wyłącznie korzystne konsekwencje rozszerzenia, a obóz „nie" upatrywał w akcesji jedynie negatywnych konsekwencji ${ }^{69}$.

\footnotetext{
66 V. M. Reyes, Reguty ..., s. 160.

67 Por. M. Leska, A. Ostrowska, Drogi ..., s. 20.

68 F. Breuss, Austria's ..., s. 15.

69 D. Phinnemore, Austria ..., s. 69.
} 


\subsection{Opinia publiczna oraz referendum akcesyjne}

Wspomniany wyżej niski poziom identyfikacji Austriaków z Europą oraz jego specyficzna rola $\mathrm{w}$ historii, $\mathrm{z}$ pewnością nie pozostawały bez wpływu na bardzo długo utrzymujący się poziom niezdecydowanych odnośnie integracji swojego państwa obywateli. Nie należy również zapominać o ówczesnej sytuacji na płaszczyźnie politycznej. Wniosek o członkostwo Austrii w Unii Europejskiej uznany został przez wielu ekspertów za szczególnie śmiałe posunięcie, co wynikało z nie do końca jasnych relacji na płaszczyźnie akcesji do Unii Europejskiej w stosunku do wieczystej neutralności ${ }^{70}$. Dodatkowo status neutralności stanowił dla Austriaków istotne źródło ich tożsamości, co miało szczególnie duże znaczenie po dwuznacznej roli, jaką naród ten odegrał podczas drugiej wojny światowej. Innym bardzo istotnym czynnikiem obniżającym poziom poparcia dla członkostwa było nagłe urzeczywistnienie możliwości jego osiągnięcia. Szczególnie powyższy argument tłumaczy spadek poparcia, który jeszcze do końca lat osiemdziesiątych utrzymywał się na relatywnie wysokim poziomie (wyk. 1).

Z powyższej perspektywy nie należy dziwić się, iż w pierwszej połowie lat dziewięćdziesiątych dopiero zakrojona na szeroką skalę kampania informacyjna doprowadziła do poparcia idei wejścia do Unii Europejskiej przez większość społeczeństwa właściwie bezpośrednio przed zapowiedzianym referendum (tab. 9).

Referendum w sprawie wejścia Austrii do Unii Europejskiej miało charakter wiążący, co wynikało z artykułu 44 Konstytucji Republiki Austrii $^{71}$. Wyznaczenie daty na 12 czerwca 1994 roku wynikało przede

70 Wniosek Austrii o członkostwo w EWG był szczególnie szeroko komentowany w Szwecji, gdzie znacznie łagodniejsza doktryna neutralności stanowiła wówczas dla Szwedów wystarczającą barierę względem możliwości uzyskania przez skandynawskie państwo członkostwa we Wspólnotach Europejskich.

71 Art. 44 Konstytucji Austrii w języku angielskim brzmi: „Article 44 [Constitutional Laws]

(1) Constitutional laws or constitutional provisions contained in simple laws can be passed by the House of Representatives only in the presence of at least half the members and by a two thirds majority of the votes cast, they shall be explicitly specified as such.

(2) Any total revision of the Federal Constitution shall upon conclusion of the procedure pursuant to Article but before its authentication by the Federal President be submitted to a referendum by the entire nation, whereas any partial revision requires this only if one third of the members of the House of Representatives or the Senate so demands". 
Wykres 1. Społeczeństwo austriackie wobec czlonkostwa w WE/UE (\%)

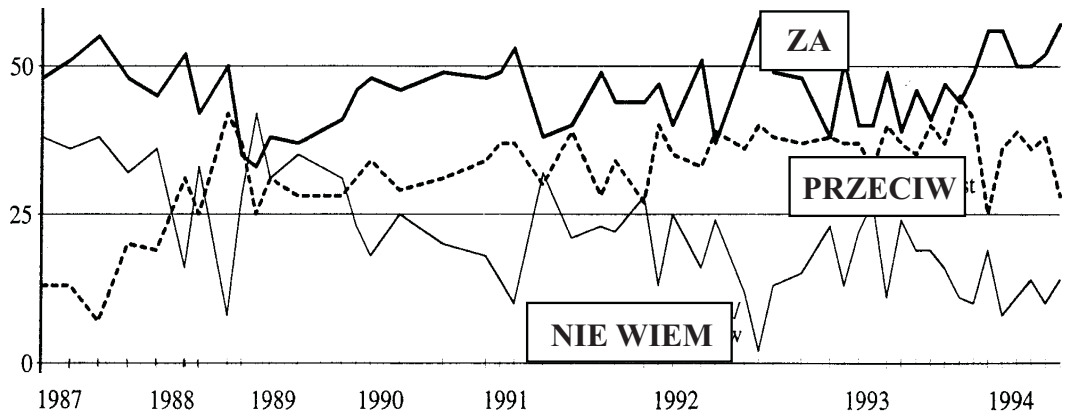

Źródło: P. Luif, On the Road to Brussels: the Political Dimension of Austria's, Finland's and Sweden's Accession to the European Union, Vienna 1995, s. 195.

wszystkim z decyzji, by plebiscyt nie odbył się tego samego dnia co wybory powszechne. Rząd miał nadzieje uniknąć w ten sposób sytuacji, w której głosujący poprzez swój wybór okazywaliby niechęć w stosunku do koalicji sprawującej władzę, co z kolei znajdowało swoje uzasadnienie w wynikach wyborów próbnych, które ukazały wysoki stopień niezadowolenia $\mathrm{z}$ partii sprawujących władzę ${ }^{72}$.

Tabela 9

Postawa społeczeństwa Austrii względem akcesji do UE oraz wynik referendum

\begin{tabular}{|c|c|c|c|}
\hline & $\begin{array}{l}\text { TAK } \\
(\%)\end{array}$ & $\begin{array}{l}\text { NIE } \\
(\%)\end{array}$ & $\begin{array}{c}\text { TRUDNO } \\
\text { POWIEDZIEĆ } \\
(\%)\end{array}$ \\
\hline Marzec, kwiecień 1993 & 40 & 39 & 21 \\
\hline Grudzień 1993 & 45 & 47 & 8 \\
\hline Styczeń 1994 & 51 & 39 & 10 \\
\hline Luty 1994 & 48 & 44 & 8 \\
\hline Marzec 1994 & 54 & 38 & 8 \\
\hline Połowa kwietnia 1994 & 53 & 30 & 17 \\
\hline Koniec kwietnia 1994 & 50 & 39 & 11 \\
\hline Maj 1994 & 54 & 35 & 9 \\
\hline Początek czerwca 1994 & 57 & 31 & 12 \\
\hline Wynik referendum - 12 czerwca 1994 & 66,6 & 33,4 & - \\
\hline
\end{tabular}

Źródło: G. Orgis, Österreichs Ja zur Europaeischen Union, w: Österreichs europaeische Zukunft: Analisen und Perspektiven, Wien 1996, podaję za: V. M. Reyes, Reguly gry czyli o negocjacjach akcesyjnych i łaczeniu się Europy, Warszawa 2000, s. 162.

72 D. Phinnemore, Austria ..., s. 68. 
Tabela 10

Wyniki referendum akcesyjnego w Austrii z podziałem według struktury społecznej

\begin{tabular}{|c|c|c|}
\hline Kategoria & Podzial & \% glosów na „TAK” \\
\hline \multicolumn{2}{|l|}{ Wynik dla całej populacji } & 66 \\
\hline \multirow[t]{2}{*}{ Płeć } & Kobiety & 62 \\
\hline & Mężczyźni & 70 \\
\hline \multirow[t]{4}{*}{ Wiek } & Do 30 lat & 55 \\
\hline & $30-44$ & 64 \\
\hline & $45-59$ & 68 \\
\hline & Powyżej 60 lat & 70 \\
\hline \multirow[t]{4}{*}{ Zawód } & Wolny & 63 \\
\hline & Rolnicy & 30 \\
\hline & Urzędnicy/Kadra kierownicza & 67 \\
\hline & Pracownicy niższego szczebla & 64 \\
\hline \multirow[t]{3}{*}{ Wykształcenie } & Podstawowe & 60 \\
\hline & Zawodowe & 65 \\
\hline & Średnie lub wyższe & 70 \\
\hline \multirow{6}{*}{$\begin{array}{l}\text { Zwolennicy partii poli- } \\
\text { tycznych }\end{array}$} & SPÖ & 73 \\
\hline & ÖVP & 66 \\
\hline & FPÖ & 41 \\
\hline & Zieloni & 38 \\
\hline & Forum Liberalne & 75 \\
\hline & Inne & 60 \\
\hline
\end{tabular}

Źródło: P. Luif, On the Road to Brussels. The Political Dimension of Austria's, Finland's and Sweden's Accession to the European Union, Vienna 1995, s. 324, thumaczenie podaje za: V. M. Reyes, Reguly gry czyli o negocjacjach akcesyjnych i łaczeniu się Europy, Warszawa 2000, s. 164.

Z liczby 4769452 biorących udział w plebiscycie 3145981 osób oddało swój głos na „tak”, natomiast 1578850 austriackich obywateli wyraziło swój sprzeciw w stosunku do akcesji. Jak ukazuje tabela 10 za przystapieniem Austrii do Unii Europejskiej głosowało więcej mężczyzn niż kobiet, a jedyną grupą zawodową, która sprzeciwiła się członkostwu byli rolnicy. Co szczególnie interesujące, zróżnicowanie według kryterium wieku ukazało, iż starsi Austriacy są większymi zwolennikami procesu integracyjnego niż młodzi obywatele Austrii.

David Phinnemore konstatuje, iż generalnie przeciw członkostwu opowiedziały się przede wszystkim osoby podchodzące pod definicje przegranych czy też ofiar modernizacji, co łączy się z niskim poziomem 
edukacji, bezrobociem, brakiem stabilności socjalnej oraz finansowej, jak również poczuciem alienacji na płaszczyźnie politycznej. Z kolei zwolennicy opierali swój wybór w pierwszej kolejności na podstawie spodziewanych korzyści ekonomicznych (39\%), drugą najistotniejszą przyczyną okazała się potrzeba uniknięcia izolacji Austrii (19\%), natomiast trzecim w rzędzie argumentem za akcesją dla Austriaków okazała się wiara w europejską jedność $(17 \%)$ na równi z ogólnymi korzyściami płynącymi z członkostwa (17\%). Miejsca pracy (14\%) oraz kwestia bezpieczeństwa $(13 \%)$ stanowiły inne argumenty przemawiające za członkostwem ${ }^{73}$.

\section{Podsumowanie}

Podejście Austrii do procesu integracji europejskiej w zasadzie od samego początku nacechowane było istotnym poczuciem rozdarcia. $\mathrm{Z}$ jednej strony wśród sześciu państw, które założyły Wspólnoty Europejskie dwa z nich - Republika Federalna Niemiec oraz Włochy - były najważniejszymi partnerami gospodarczymi środkowoeuropejskiego kraju, przy czym niekorzystne konsekwencje powyższej sytuacji dodatkowo wzmagał fakt, iż ze względu na niewielką liczbę mieszkańców, Austria - podobnie jak dwa pozostałe państwa, które weszły do UE w 1995 roku w znacznej mierze opierała swoją gospodarkę na zewnętrznych stosunkach handlowych. Z drugiej strony Austriacy zobowiązani byli do przestrzegania doktryny neutralności, której przyjęcie określić można jako swego rodzaju cenę za uzyskanie pełnej niepodległości po kontrowersyjnej roli, jaką państwo to odegrało w trakcie drugiej wojny światowej. W związku z powyższym zmiana sytuacji międzynarodowej na przełomie lat osiemdziesiątych i dziewięćdziesiątych XX wieku oznaczała dla Austriaków pojawienie się możliwości dokonania istotnych zmian w zakresie swojej roli na płaszczyźnie stosunków międzynarodowych, którą w okresie zimnej wojny należy określić jako przynajmniej umiarkowaną, co potwierdzić może opinia Paula Henri Spaaka, który Austrię postrzegał wyłącznie jako wartościowy „kraj-most” pomiędzy Włochami a resztą kontynentu $^{74}$. W rezultacie najważniejsze austriackie ugrupowania polityczne bardzo szybko zdecydowały się na dążenie do uzyskania przez

73 Ibidem.

74 T. Pedersen, European Union and the EFTA Countries. Enlargement and Integration, London 1994, s. 80. 
Austrię członkostwa we Wspólnotach Europejskich, a austriackie społeczeństwo poparło powyższą ideę w przeprowadzonym w 1994 roku referendum.

Przypadek Austrii ukazuje przy tym przynajmniej dwie bardzo istotne kwestie w kontekście uzyskiwania członkostwa w Unii Europejskiej. Po pierwsze, nawet bardzo wysoki poziom gospodarczy kraju (PKB powyżej średniej dotychczasowych państw członkowskich UE), jak również znaczny stopień zintegrowania z Unią jeszcze przed jej przystapieniem (członkostwo w EOG) nie wystarczyły by społeczeństwo austriackie nie odczuło negatywnych konsekwencji bezpośrednio po akcesji. Jest to przy tym ściśle związane z drugim ważnym zjawiskiem. Silny wzrost negatywnej postawy w stosunku do członkostwa w społeczeństwie austriackim bezpośrednio po akcesji w dużej mierze wynikał ze zbyt rozbudzonych oczekiwań względem korzyści, jakie miały stać się jego udziałem po przystapieniu. W powyższym kontekście należy zadać zasadnicze pytanie o właściwą strategię informacyjną poprzedzającą wejście do Unii Europejskiej w Austrii. Co prawda jednostronna kampania do złudzenia przypominająca marketingową promocję produktu rynkowego zapewniła najwyższy wśród państw trzeciej fali rozszerzeniowej (1995) poziom poparcia w referendum akcesyjnym. Z drugiej strony w konsekwencji tego rodzaju metody informowania bezpośrednio po przystapieniu nastapiło drastyczne obniżenie poziomu poparcia dla procesu integracyjnego. Jeżeli zatem wyjdziemy z założenia, iż z perspektywy elit decyzyjnych członkostwo w UE stanowi priorytetowy cel, należy austriacki przykład postawić na jednym końcu, natomiast po drugiej stronie znajdowałyby się norweskie doświadczenia, gdzie przyjęcie formy debaty opartej o standardy demokracji partycypacyjnej na temat akcesji przyniosło negatywny wynik w referendum akcesyjnym. $Z$ tego punktu widzenia wyciaganie jednoznacznych wniosków wydaje się zadaniem niełatwym. Można jednak zaryzykować tezę, iż nieco mniejszy poziom obietnic składanych Austriakom przed przystąpieniem nie wpłynąłby w kluczowy sposób na wyniki ogólnonarodowego plebiscytu, mógłby natomiast przyczynić się do zmniejszenia poziomu oczekiwań w stosunku do członkostwa. Niezależnie od powyższych hipotez należy na podstawie powyższych doświadczeń podkreślić subiektywną stronę obecną w procesie oceny przez społeczeństwo konsekwencji rozszerzenia, jak również zaznaczyć, iż akcesja sama w sobie powinna być interpretowana w większym stopniu jako zwiększenie możliwości na rozwój, niż jako pewnik iż ten jest zagwarantowany przez sam fakt przystąpienia do UE. 


\section{Bibliografia}

Bieler A., Globalisation and Enlargement of the European Union. Austrian and Swedish Social Forces in the Struggle over Membership, London-New York 2000.

Breuss F., Austria's Approach towards the European Union, IEF Working Paper Nr 18, April 1996.

Ciszak T., Herma C., Hykawy R., Rozszerzenie UE o kraje EFTA, „Biuletyn Analiz UKIE", nr 6, maj 2001.

Dokumenty dotyczqce przystapienia do Unii Europejskiej Austrii, Finlandii i Szwecji, red. J. Plaňavová-Latanowicz, CEUW, t. 3, Warszawa 1998.

Eisl G., Austria's Experiences before and after its Entry to the European Union, w: The Experiences of the 1995 Enlargement. Sweden, Finland and Austria in the European Union, eds. J. Jańczak, T. R. Szymczyński, Logos, „Thematicon”, Bd 9; Berlin 2003.

European Commision, Opinion on Austria's Application for Membership, „Bulletin of the European Communities, Supplement 4/92.

Falkner G., The Europeanisation of Austria: Misfit, Adaptation and Controversies, „European Integration online Papers - EIoP”, Vol. 5, No. 13, December 2001.

Fidrmuc J., Pichelmann K., Austriackie doświadczenia wynikajace z przystapienia do Unii Europejskiej, w: Doświadczenia negocjacji akcesyjnych państw UE, red. S. Miklaszewski, Kraków 2000.

Gehler M., Österreichs Weg nach Bruessel bis zum Stellen der Beitrittsgesuche, w: Österreich und Europa. Beitraege zu Geschichte und Problematik der europaeischen Einigung um die Jahrtausendwende, Hrsg. R. Kriechbaumer, Wien 2000.

Granell F., The First Enlargement Negotiations of the EU, w: The 1995 Enlargement of the European Union, ed. J. Redmond, Aldershot 1997.

Hamel S., ,,Eine solche Sache wuerde der Neutraliaetspolitik ein Ende machen”. Die österreichischen Integrationsbestrebungen 1961-1972, w: Österreich und die Europaeische Integration 1945-1993, Hrsg. M. Gehler, R. Steininger, Wien 1993.

Konopacki S., Przystapienie Szwecji do Unii Europejskiej, „Studia Europejskie” 2001, nr 2.

Koszel B., Austria w procesie integracji Polski z Uniq Europejska, „Opinie”, MSZ, Warszawa 2003.

Lauber V., Wirtschafts- und Finanzpolitik, w: Handbuch des politischen Systems Österreichs, Wien 1997.

Leitner G., Der Weg nach Bruessel. Zur Geschichte des österreichischen EG-Beitrittsantrages vom 17. Juli 1989, w: Österreich und die Europaeische Integration 1945-1993, Hrsg. M. Gehler, R. Steininger, Wien 1993. 
Leska M., Ostrowska A., Drogi do Unii Europejskiej. Narodowe strategie informacyjne, Warszawa 1998.

Luif P., On the Road to Brussels. The Political Dimension of Austria's, Finland's and Sweden's Accession to the European Union, Vienna 1995.

Luif P., Österreich, w: Europa-Handbuch, Hrsg. W. Weidenfeld, Bonn 1999.

Miles L., Sweden and European Integration, Aldershot-Brookfield 1997.

Neal L., Barbezat D., The Economics of the European Union and the Economies of Europe, New York-Oxford 1998.

Negocjacje akcesyjne. Wnioski z doświadczeń Austrii, Finlandii, Norwegii i Szwecji, Natolin 1999, s. 32.

Olejniczak D., Austria, w: Okresy przejściowe w Traktatach o przystapieniu do Europejskiej (wybrane przyklady: Hiszpania, Portugalia, Austria, Finlandia, Szwecja), Zespół Integracji Europejskiej (opracowanie zbiorowe), Biuro Studiów i Ekspertyz, Raport nr 145/1999.

Österreichisches Bundesgesetzblatt Nr 211/1955.

Pedersen T., European Union and the EFTA Countries. Enlargement and Integration, London 1994.

Phinnemore D., Austria, Transit and the Environment, w: The 1995 Enlargement of the European Union, ed. J. Redmond, Aldershot 1997.

Plan̆avová-Latanowicz J., Wprowadzenie, w: Dokumenty dotyczqce przystapienia do Unii Europejskiej Austrii, Finlandii i Szwecji, red. J. Plaňavová-Latanowicz, CEUW, t. 3, Warszawa 1998.

Preston C., EFTA, the EU and the EEA, w: The 1995 Enlargement of the European Union, ed. J. Redmond, Aldershot-Vermont 1997.

Preston C., Enlargement \& Integration in the European Union, Routledge, London-New York 1997.

Reyes V. M., Reguty gry czyli o negocjacjach akcesyjnych i łaczeniu się Europy, Warszawa 2000.

Scheich M., Das Brechen eines politischen Tabus - Österreichs Weg in die EU, w: Österreich und Europa. Beitraege zu Geschichte und Problematik der europaeischen Einigung um die Jahrtausendwende, Hrsg. R. Kriechbaumer, Wien 2000.

Szymczyński T. R., Droga Wielkiej Brytanii do członkostwa we Wspólnotach Europejskich-1964-1975, „Przegląd Politologiczny” 2003, nr 4.

Szymczyński T. R., Kontrowersje wokół postawy Wielkiej Brytanii względem procesu zjednoczeniowego w Europie Zachodniej po II wojnie światowej, w: Dylematy integracji europejskiej. Europa Środkowo-Wschodnia u progu rozszerzenia Unii Europejskiej, red. R. Kmieciak, T. Wallas, UAM, Poznań 2004.

Szymczyński T. R., Od planu Schumana do weta de Gaulle'a. Wielka Brytania poza procesem integracji europejskiej - 1950-1963, „Przegląd Politologiczny”, UAM, Poznań 1/2003. 
Urlesberger F., Die Marginalisierung Österreichs im europaeischen Integrationsgeschehen nach Aufloesung der OEEC/OECD, w: Österreichs Integration in Europa 1948-1989, Wien 1990.

Wereszycki H., Historia Austrii, Wrocław-Warszawa-Kraków-Gdańsk-Łódź 1986.

\section{Summary}

In the Author's opinion the case of Austria demonstrates at least two highly significant issues in the context of obtaining membership of the EU. Firstly, even an economically highly developed country (GNP in excess of the average level of the EU member states) as well as a considerable degree of integration with the EU even prior to the accession (EEA member) did not suffice to prevent Austrian society from experiencing negative consequences immediately after the accession. This is strictly related to the other significant phenomenon. A considerable increase of negative approaches towards membership, emerging among Austrian society, to a significant degree resulted from the excessive expectations of the merits which were supposed to be shared by the society following the accession. 